\title{
Penerapan Fungsi Actuating Pesantren dalam Upaya Pembinaan Tahfidz
}

\author{
Nur Sakinah ${ }^{1 *}$, Dadang Kuswana $1^{1}$, Yuliani $2^{2}$ \\ ${ }^{1}$ Jurusan Pengembangan Masyarakat Islam, Fakultas Dakwah dan Komunikasi, UIN Sunan \\ Gunung Djati, Bandung

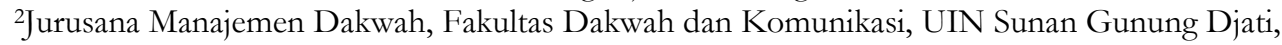 \\ Bandung \\ *Email:nur.sakinah@student.uinsgd.co.id
}

\begin{abstract}
ABSTRAK
Tujuan dari penelitian ini adalah untuk mengetahui bagaimana penerapan fungsi actuating dalam upaya pembinaan tahfidz di Pesantren Bina Insan Mulia AlMawahib. Metode yang digunakan dalam penelitian ini adalah metode deskriptif. Adapun teknik pengumpulan datanya adalah melalui kegiatan obsevasi, wawancara dan studi dokumentasi. Dari penelitian ini diperoleh informasi bahwa proses actuating yang dilakukan pesantren Bina Insan Mulia Al Mawahib: yaitu mengadakan perekrutan santri sebelum masuk ke pesantren, pelaksanaan koordinasi, mobilisasi dan alokasi sumber daya, pemberian motivasi, penambahan hafalan, pembagian kelompok santri tahfidz, pemberian sanksi bagi santri yang tidak mencapai target, penentuan target hafalan, pengawasan pembinaan tahfidz, program unggulan tahfidz di pesantren, penentuan jumlah target hafalan dalam setiap semester, pengawasan dari Pembina tahfidz terhadap santri dan pengembangan pembinaan tahfidz terhadap santri, program unggulan dalam menghafal Alquran. adanya kendala pembina tahfidz, faktor pendukung atau penunjang santri dalam menghafal Alquran. Selanjutnya Upaya-upaya yang dilakukan di Pesantren Bina Insan Mulia Al Mawahib dalam pembinaan tahfidz terhadap santri agar pelaksanaan pembinaan tahfidz berjalan dengan baik. Upaya tersebut senantiasa berupaya untuk membina tahfidz dengan tetap menjaga kualitas dan kuantitas juga metode dalam pembinaan tahfidz seperti (1) ngaji bersama,(2) sualan,(3)sima'an(4) tasmi dan(5) talaqqi.
\end{abstract}

Kata Kunci : Fungsi Actuating; Pesantren; Pembinaan; Tahfidz.

\section{ABSTRACT}

The purpose of this research is to find out how the implementation of actuating function in the effort of fostering tabfidz in Pesantren Bina Insan Mulia Al-Mawabib. The method used in this research is descriptive method. The data collection technique is through obsevation, 
interview and documentation study. From this research, it is found that actuating process conducted by Pesantren Bina Insan Mulia Al Mawabib: that is holding recruitment of santri before entering pesantren, implementation of coordination, mobilization and resource allocation, giving motivation, addition of rote, division of tahfidz santri group, giving sanction for santri who do not reach the target, the targeting of memorization, the supervision of tabfidz. development, the tahfidz superior program in pesantren, the determination of the target number of memorization in every semester, the supervision of the tabfidz coach towards the students and the development of tahfidz's guidance to the students, the excellent program in memorizing the Quran. the existence of constraints tabfidz builder, supporting factors or supporting santri in memorizing the Quran. Further Efforts made in Pesantren Bina Insan Mulia Al Mawabib in coaching tahfidz against santri for the implementation of tabfidz coaching goes well. The effort always strives to foster tabfidz while maintaining the quality and quantity as well as the method of fostering tabfidz such as (1) Ngaji together, (2) sualan, (3) sima'an (4) tasmi and (5) talaqqi.

Keywords: Actuating Function; Pesantren; Coaching; Tahfidz.

\section{PENDAHULUAN}

Melihat realitas masyarakat Indonesia khususnya umat Islam, banyak sekali orang yang berpendidikan tetapi belum banyak yang berkeinginan untuk menghafal Alquran. Oleh karena itu salah satunya pesantren diharapkan dapat membenahi kekurangan dalam pendidikan, dengan adanya program tahfidz Alquran. Fungsi actuating dalam pembinaan tahfidz Alquran diharapkan dapat meningkatkan minat santri dalam menghafal Alquran. Pondok pesantren diharapkan dapat meningkatkan diri sebagai salah satu kekuatan agama Islam yang sejajar dengan pendidikan yang lainnya.

Istilah pondok pesantren di Indonesia telah populer dikalangan masyarakat. Karena lembaga ini telah tersebar menempati beberapa daerah di tanah air. Pondok pesantren ini merupakan kata majemuk yang tersusun dari "pondok" dan "pesantren". Rangkaian kedua kata ini apabila dipisahkan memiliki arti tersendiri.

Menurut pendapat Zamkhsyari Dhofier (1990: 19) istilah "pondok" berasal dari pengertian "asrama-asrama para santri atau tempat tinggal yang dibuat dari bambu" atau barangkali berasal dari kata Arab, Funduq, yang berarti "Hotel atau asrama". Sedangkan istilah "pesantren" adalah berasal dari kata "santri" yang dengan tambahan awalan "pe" dan akhiran "an" berarti tempat tinggal para santri.

Pesantren lahir sebagai keinginan umat islam yang ingin menerapkan nilai nilai islam telah mendapat jawaban dengan semakin banyaknya dan berkembangnya pesantren. Diantara pesantren yang ada didampingi adanya sekolah, diharapkan dengan berkembangnya pesantren ini bisa menjadi lebih baik lagi. 
Pada tingkat pertama dapat dikatakan bahwa pesantren -pesantren adalah suatu lembaga keagamaan yang mengajarkan, mengembangkan dan menyebarkan (da'wah) ilmu agama Islam. Keberadaan pesantren sebagai wadah untuk memperdalam agama dan sekaligus sebagai pusat penyebaran agama Islam diperkirakan sejalan dengan gelombang pertama dari proses pengislaman di daerah Jawa yang berakhir sekitar abad ke-16 (Dhofier, 1982). Mereka yang berhasil dalam belajarnya, memang kemudian diharapkan menjadi kiai, ulama mubaligh, setidak - tidaknya guru agama dan ahli agama.

Pembinaan adalah suatu proses dimana orang-orang mencapai kemampuan tertentu untuk membantu mencapai tujuan organisasi. Oleh karena itu, proses ini terkait dengan berbagai tujuan organisasi, pembinaan dapat dipandang secara sempit maupun luas (Mathis, 2002: 112).

Salah satu upaya pembinaan tahfidz Al-Qur'an diantaranya, dengan menggunakan metode talaqqi, talaqqi yaitu siswa menghafal, melafalkan dan melagamkan Al-Qur'an sesuai dengan yang dicontohkan oleh guru pembimbing masing-masing, kemudian diikuti oleh siswa yang kemudian dibenarkan oleh guru pembimbing jika terjadi kesalahan pelafalan.

Actuating adalah suatu tindakan untuk mengusahakan agar semua anggota kelompok berusaha untuk mencapai sasaran yang sesuai dengan perencanaan manajerial dan usaha-usaha organisasi. Jadi, actuating artinya menggerakkan orang-orang agar mau bekerja dengan sendirinya atau dengan kesadarannya secara bersama-sama untuk mencapai tujuan yang dikehendaki secara efektif.

George R. terry mengemukakan bahwa "actuating is setting all members of the group to want to achieve and to strike to achieve the objective willingly ang keeping with the managerial planning and organizing efforts". Pengarahan adalah membuat semua anggota. kelompok, agar mau bekerja sama secara ikhlas serta bergairah untuk mencapai tujuan sesuai dengan perencanaan dan usaha usaha pengorganisasian.

Fungsi actuating menjadi salah satu bagian dari metode mempengaruhi minat santri dalam menghafal Alquran. Melihat realita saat ini masih banyak anak anak yang kurang memiliki minat dalam menghafal Alquran, dikarenakan tidak bisa membaca Alquran, tidak memiliki dasar hafalan Alquran, dan malas menghafal Alquran. Dengan adanya fenomena tersebut maka salah satu faktor pendukung diadakannya program pembinaan tahfidz di Pesantren Bina Insan Mulia Al Mawahib yaitu ingin mencetak anak tahfidz, pesantren ini membangun dan membimbing para santri menggali potensi anak anak yang ingin belajar Alquran dan ingin menghafal Alquran serta mengamalkannya, sehingga harapan dari pesantren ini dapat tercapai.

Fungsi actuating di pesantren dalam pembinaan tahfidz di Pesantran Bina Insan Mulia Al Mawahib mencapai taraf usaha maksimal, disamping ketersediaan pesantren di kembangkan juga metode penerapan actuating untuk proses 
pembinaan tahfidz untuk mengembangkan potensi santri dalam menghafal Alquran sehingga menjadi santri yang unggul.

Dalam hal ini terdapat dalam jajaran pengurus pesantren sebagai pengaplikasian actuating ada pemimpin sebagai pengawas dan yang memberi kebijakan dalam setiap kegiatan yang berhubungan dengan aktivitas di pesantren, sekertaris, bendahara, guru-guru yang mengajar dan dewan asatidz sebagai pembimbing tahfidz, yang berhak memberikan pengaplikasian actuating penghafalan Alquran, dan Asatidzah sebagai pembimbing santri.

Pada masa menjadi santri adalah masa yang sangat penting, jika santri menghafal Alquran secara menyeluruh lalu memahami dan mengamalkannya, maka santri tersebut adalah manusia yang cerdas dengan itu akan terbentuk manusia yang unggul dalam hafalan Alquran nya dan juga pengamalannya.

Masalahnya adalah bagaimana memotivasi minat santri dalam meningkatkan hafalan dan mengamalkannya, ini merupakan hal yang sulit untuk mencari pengaplikasian actuating yang tepat bagi guru sebagai pembimbing yang mengajari begitupun santri yang menghafalnya, agar hafalannya lancar meningkat dan juga mengamalkannya, agar menjadi manusia yang unggul.

Dengan demikian, actuating dalam pembinaan tahfidz Alquran merupakan upaya memperbaiki bacaan Alquran, meningkatkan hafalan Alquran, menyempurnakan bacaan Alquran, mengarahkan bacaan dan hafalan Alquran dan mengembangkan kemampuan untuk mencapai tujuan agar sarana pembinaan mampu menghayati dan mengamalkan ajaran islam sebagai pola kehidupan sehari-hari baik dalam kehidupan pribadi, maupun kehidupan sosial masyarakat.

Lokasi penelitian ini dilaksanakan di Pesantren Bina Insan Mulia Al Mawahib Perum Gading Tutuka 2, Jalan Raya Banjaran Soreang, Desa Ciluncat Kecamatan Cangkuang Kabupaten Bandung. merupakan upaya memperbaiki bacaan Alquran, meningkatkan hafalan Alquran.

Dari latar belakang masalah di atas dapat dirumuskan beberapa masalah dengan rumusan: pertama, bagaimana penerapan fungsi actuating di Pesantren Bina Insan Mulia Al Mawahib Perum Gading Tutuka 2, Jalan Raya Banjaran Soreang, Desa Ciluncat Kecamatan Cangkuang Kabupaten Bandung? Kedua, bagaimana upaya pembinaan tahfidz yang dilakukan di Pesantren Bina Insan Mulia Al Mawahib?

Metode yang digunakan dalam penelitian ini adalah metode deskriptif. adapun teknik pengumpulan datanya adalah melalui kegiatan obsevasi, wawancara dan studi dokumentasi.

\section{LANDASAN TEORITIS}

Teori yang digunakan dalam penelitian ini adalah teori yang dikemukakan oleh Sukmadi (2012: 78) dimana fungsi actuating terdiri dari koordinasi kegiatan dan 
alokasi sumber daya fisik serta dana yang diperlukan. Menurut Sukmadi, koordinasi penting dilakukan untuk memastikan semua kegiatan terlaksana sesuai rencana dan tepat waktu. Koordinasi kegiatan ini meliputi mengorganisasikan, mengarahkan dan mengawasi.

Actuating berasal dari kata actuate (bahasa latin) yang berarti pengarahan. To actuate dalam Webster's New Collegiate Dictionary di beri penjelasan to put into action, to incite to, action, atau yang berarti menggerakkan, atau mendorong untuk bergerak.

Actuating (directing $=$ leading commending $=$ motivating $=$ pelaksanaan) merupakan fungsi manajemen yang terpenting dan paling dominan dalam proses manajemen. Fungsi ini baru dapat diterapkan setelah rencana organisasi dan karyawan ada. Jika fungsi ini diterapkan maka proses manajemen dalam merealisasikan tujuan dimulai. Penerapan fungsi ini sangat sulit, rumit dan kompleks karena karyawan tidak dapat dipengaruhi sepenuhnya. Hal ini disebabkan karena karyawan adalah makhluk hidup yang punya akal, perasaan, harga diri, cita-cita dan lain-lain. Pelaksanaan pekerjaan dan pemanfaatan alat-alat bagaimanapun canggih dan handalnya, baru dapat dilakukan jika karyawan ikut berperan aktif melaksanakannya. Fungsi actuating ini adalah ibarat stater mobil, artinya baru dapat dikerjakan jika kunci staternya telah melaksanakan fungsinya. Demikian juga proses manajemen baru dapat terlaksana setelah fungsi actuating ini diterapkan.

Menurut Muchtarom dalam Sayyid Muhammad Ulil Absor (2005: 26), Setelah planning disusun dan pekerjaan telah terbagi, maka langkah selanjutnya yang dilakukan oleh pemimpin ialah mengarahkan orang-orang untuk melakukan pekerjaan secara efektif dan efisien berdasarkan planning dan pembagian tugas masing-masing. Langkah-langkah yang dilakukan pimpinan untuk mengarahkan organisasi sehingga berjalan kearah tujuan yang ingin dicapai inilah yang biasa disebut pengarahan atau actuating.

Beberapa hal yang penting untuk diperhatikan dalam pelaksanaan actuating ini adalah bahwa seorang karyawan akan termotivasi untuk mengerjakan sesuatu jika: pertama, merasa yakin akan mampu mengerjakan; kedua, yakin bahwa pekerjaan tersebut memberikan manfaat bagi dirinya; ketiga, tidak sedang dibebani oleh masalah pribadi atau tugas lain yang lebih penting atau mendesak; keempat, tugas tersebut merupakan kepercayaan bagi yang bersangkutan; kelima, hubungan antar teman dalam organisasi tersebut harmonis.

Karel. A. Steenbrink (1986: 21), mengemukakan bahwa istilah Pondok mungkin berasal dari bahasa Arab, Funduq yang berarti pesanggrahan atau penginapan bagi orang-orang yang berpergian.

Istilah Pondok dalam kamus bahasa Indonesia adalah "Rumah untuk sementara waktu, seperti didirikan di ladang, di hutan, dikatakan Pondok adalah 
Rumah yang kurang baik biasanya berdinding bilik atau dikatakan Pondok adalah Madrasah dan asrama tempat mengaji, belajar Agama Islam" (Dhofier, 1982: 18).

Pesantren adalah gabungan kata "Sant (Manusia Baik)" dihubungkan dengan suku kata "tra (Suka Menolong)" sehingga kata Pesantren dapat berarti tempat pendidikan manusia baik-baik (Ziemek, 1986: 99).

Menurut Galba dalam Yudi Sevenpri (2002:24) Kata pondok berasal dari bahasa arab "funduq" yang berarti tempat menginap atau asrama. Asrama yang dimaksud disini ialah sebuah tempat yang mempunyai tempat dan fungsi pendidikan dakwah Islam. Sedangkan pesantren berasal dari kata "santri" yang diberi awalan "pe-an", bahasa tamil yang berarti para penuntut ilmu guru mengaji.

Menurut Muhammad Ridwan Lubis (1992: 23), Pesantren dan santri berasal dari bahasa Tamil yang berarti: Guru mengaji, sumber lain mengatakan bahwa kata itu berasal dari bahasa India Shastri dari akar kata shastra, yang berarti buku-buku suci, buku agama atau buku-buku tentang Ilmu pengetahuan. Dengan demikian Pondok Pesantren adalah perpaduan dua kata yang dirangkaikan menjadi satu, yaitu terdiri dari kata Pondok dan Pesantren. Sampai saat ini masih ada perbedaan pendapat mengenai asal-usul tentang Pondok Pesantren yaitu, ada yang mengatakan berasal dari India (Hindu) dan ada pula yang mengatakan berasal dari Arab.

Adapun yang mengatakan bahwasannya Pesantren dari India adalah Soegarda Poerbakawatja yang menjelaskan bahwa adanya persamaan dalam penyerahan tanah oleh negara bagi kepentingan agama yang terdapat pada tradisi Hindu. Adanya persamaan ditemukan sistem pendidikan Hindu dengan Pesantren, yaitu guru tidak mendapatkan gaji, letak Pesantren diluar kota dan seluruh sistem pendidikan bersifat agama.

Pesantren seringkali dianggap sebagai lembaga pendidikan yang hanya bertugas untuk mendidik seseorang menjadi manusia yang berilmu. Namun akhir-akhir ini paradigma umat muslim khusus sudah berkembang, mulai dari yang menganggap pesantren sebagai lembaga pendidikan klasik yang identik dengan pendidikan baca Al-Qur'an, pendidikan fikih, pendidikan ceramah atau khutbah, dan lebih cenderung bersifat keakhiratan, namun paradigma tersebut sudah beralih menjadi paradigma yang lebih modern tidak hanya terfokus pada aspek keakhiratan saja melainkan aspek keduniaan juga. (Adrian, 2017)

Peran dan fungsi pesantren bukanlah sesuatu yang statis dan kaku, akan tetapi tentunya mengalami suatu perkembangan seiring dengan perkembangan pola hidup masyarakat sebagai wujud dari dinamika kehidupan yang sering kali melahirkan berbagai problematika hidup yang semakin kompleks. Oleh karena itu sebagai upaya untuk memahami peran dan fungsi pondok pesantren secara lebih jelas, maka tentunya harus mampu meninjau tiga fase utama perjalanan pondok pesantren, yaitu pada awal masa berdirinya, masa penjajahan belanda, 
serta masa sekarang ini.

Pada masa awal berdirinya, pondok pesantren hanya berfungsi sebagai alat islamisasi sekaligus memadukan tiga unsur pendidikan yakni:

Ibadah untuk menanamkan keimanan, tabligh untuk meyebarkan ilmu, dan amal untuk mewujudkan kemasyarakatan dalam kehidupan sehari hari. Hal ini pun seiring dengan pendapat Didin Hafidhudin yang menyatakan bahwa "pondok pesantren memiliki dua fungsi utama yaitu taffaqquh fi ad-diin, dan indzar atau upaya untuk mendakwahkan ajaran islam kepada masyarakat"

Dalam Kamus Besar Bahasa Indonesia pengeritan upaya adalah usaha atau ikhtiar (untuk mencapai suatu maksud, memecahkan persoalan, mencari jalan keluar, dan sebagainya).

Menurut KBBI dalam Epa Sumarni (2016: 25), Pembinaan berasal dari kata bina yang artinya bangun. Apabila di beri awalan me- maka membina, yang artinya membangun, mendirikan, mengusahakan agar lebih baik. Sehingga pembinaan mengandung arti proses, tindakan dan kegiatan yang dilakukan secara berdaya guna unruk memperoleh hasil yang lebih baik. Menurut Mifta Thaoha, pembinaan adalah suatu tindakan, proses, hasil atau pernyataan menjadi lebih baik. Dalam hal ini menunjukkan adanya kemajuan, peningkatan, pertumbuhan dan evolusi atas berbagai kemungkinan yang berkembang atau peningkatan atas sesuatu. Ada dua unsur dari pengertian ini, yakni pembinaan itu sendiri bisa berupa suatu tindakan, proses atau pernyataan dari suatu tujuan dan kedua pembinaan itu bisa menunjukkan kepada perbaikkan atas sesuatu.

Menurut W.J.S. Poerwadarminta (1986: 141) dalam Aid Samsudin (2007: 27) Pengertian pembinaan ditinjau dari akar katanya berasal dari bahasa arab yaitu bana, yabni binaan yang mempunyai arti bangun, membangun dan melaksanakan.

Menurut Zaini, Tabfidz Al-Qur'an terdiri dari dua kata yaitu tabfidz dan AlQur'an. Kata tahfidz adalah bentuk masdar ghoir mim dari kata حَفََّ - يُحَفِظظ - تَحْفِيْظً yang mempunyai arti menghafalkan. Sedangkan menurut Abdul Aziz Abdul Rauf definisi tabfidz atau menghafal adalah proses mengulang sesuatu, baik dengan membaca atau mendengar. Pekerjaan apapun jika sering diulang, pasti menjadi hafal.

Salah satu upaya yang dapat dilakukan untuk dapat menghafalkan AlQur'an serta senantiasa menjaga hafalannya adalah dengan melakukan pembinaan serta menggunakan metode-metode tertentu.

Dalam menghafal Al-Qur'an orang mempunyai metode dan cara yang berbeda-beda. Namun, metode apapun yang dipakai tidak akan terlepas dari pembacaan yang berulang-ulang sampai dapat mengucapkannya tanpa melihat mushaf sedikitpun. Proses menghafal Alquran dilakukan melalui proses bimbingan seorang guru tahfizh. 


\section{HASIL DAN PEMBAHASAN}

Proses penyelenggaraan pendidikan Madrasah Aliyah (MA) Bina Insan Mulia, tidak bisa di pisahkan dari kiprah seorang ulama bernama K.H Abdul Wahab Mawahib yang semasa hidupnya aktif dalam berbagai organisaasi keislaman ditanah air.

Setelah dinyatakan siap terjun dimasyarakat oleh guru ngajinya semasa di pesantren, yaitu Mama K.H Ruhiyat, saat itu adalah pimpinan pondok pesantren Cipasung Singaparna Tasikmalaya, bertolaklah Bapak K.H Abdul Wahab Mawahib dari kota kelahirannya Tasikmalaya menuju kota Bandung. Kemudian setelah memiliki ketepatan kuat bahwa kota Bandung adalah tempat yang paling tepat untuk mengembangkan dakwah Islamnya, maka bersama isteri tercintanya Hj. Siti Sofiatur Romah pendididkan Islam mulai dikembangkan, tepatnya dijalan Tamansari Bawah Kota Bandung.

Berkat dukungan dari berbagai pihak, terutama masyarakat setempat, maka perkembangan dakwah pendidikan Islam di tempat itu berhasil dengan baik. Kini di tempat itu sudah berdiri sebuah yayasan milik masyarakat bernama Yayasan Mathla'ul Khairiyah. Yayasan itu kini sepenuhnya berada dalam kepengurusan masyarakat setempat, termasuk beberapa putra dan putri Mama K.H Abdul Wahab turut bertanggung jawab memelihara keberadaan yayasan itu. Yayasan itu kini telah memiliki sebuah lembaga pendidikan formal, madrasah diniyah, masjid, majlis taklim, dengan beragam program yang di butuhkan oleh masyarakat.

Semasa hidupnya pasangan almarhum KH. Abdul Wahab dan Hj. Siti Sofiatur Romlah mengharapkan perjuangan mereka dalam mengembangkan pendidikan Islam biasa terus menerus dilaksanakan tanpa mengenal putus. Harapan tersebut disampaikan kepada semua ahli warisnya, yaitu generasi penerus selanjutnya, putra putri para cucu, dan cicit-cicitnya.

Gagasan pertama pasangan tersebut adalah membangun sebuah pondok pesantren modern di kota Bandung. Pembangunan pondok ini bertujuan untuk melayani masyarakat dalam memperoleh pendidikan berkualitas secara menyeluruh, dari mulai pendidikan usia dini hingga perguruan tinggi. Program pendidikan yang diselenggarakan harus memiliki visi dan misi Islam, yaitu mewujudkan manusia bermutu (khaira ummah) yang memeiliki karakteristik itba'syari'atillah dan itba'sunnatillah. Artinya, program pendidikan yang dilaksanakan harus mampu menghasilkan para pemimpin masa depan yang terampil menguasai ilmu pengetahuan dan teknologi; menguasai lmu agama Islam dan sumber rujukannya; mempunyai daya juang yang tinggi; kreatif, inovatif, proaktif, serta memiliki landasan iman dan taqwa yang kuat.

Harapan tersebut bukan hanya sekedar wacana belaka $\mathrm{Hj}$. Siti Sofiatur Romlah yang berlokasi dipinggiran sungai Cisakuy daerah Banjaran Kabupaten Bandung. Satu buah bangunan rumah yang terletak di jalan Tamansari bawah 
No. 47/59 RT 02 RW 20 Kota Bandung, serta satu sebuah unit mobil L-300 adalah bukti kesungguhan almarhum/ almarhumah untuk segera mewujudkan sebuah lembaga pendidikan pondok pesantren demi memberikan pelayanan pendidikan kepada masyarakat.

Gagasan pasangan Almarhum K.H Abdul Wahab dan Hj. Siti Sofiatur Romlah tersebut dianggap oleh para penerusnya sebagai amanah yang harus diwujudkan. Kemudian oleh para pewarisnya, terutama generasi pertama dan kedua, gagasan mulia itu dituangkan dalam bentuk pendirian sebuah yayasan bernama, Yayasan Bina Insan Mulia Al-Mawahib. Yayasan yang berdiri sejak tahun 2010 ini, tepatnya hari Rabu, Juli 2010, selanjutnya merencanakan berbagai program pendidikan formal dan non formal secara integratif dan mulai pendidikan usia dini hingga perguruan tinggi.

Dengan berbagai pertimbangan, dan dalam rangka memenuhi kebutuhan nasional akan sumber daya berkualitas tinggi dalam penguasaan iptek sekaligus kuat dalam iman dan taqwa (imtaq), maka atas prakarsa pengurus Yayasan Bina Insan Mulia Al-Mawahib pada tahun ini program pembangunan unit pendidikan Madrasah Bina Insan Mulia mulai dilaksanakan. Jadi Madrasah Bina Insan Mulia adalah salah satu unit pendididkan di bawah naungan yayasan Bina Insan Mulia Al-Mawahib.

Madrasah Bina Insan Mulia Al-Mawahib ini memiliki ciri khas tertentu, diantaranya bermodel pesantren modern, memiliki keunggulan dalam penguasaan dakwah, penguasaan Alquran pengusaan IPTEK DAN IMTAQ.

Berdirinya Madrasah Aliyah Bina Insan Mulia merupakan wujud kepedulian masyarakat yang diwakili oleh yayasan Bina Insan Mulia Al-Mawahib terhadap mutu pendidikan, khususnya pendidikan Islam. Madrasah Bina Insan Mulia Al-Mawahib memiliki dua program khusus, yaitu program pendidikan dakwah komunikasi dan penyiaran Islam (Dikdakompi), serta program dakwah teknologi informasi dan komunikasi (Daktikom).

Demi keberhasilan program pendidikan ini, maka Yayasan Bina Insan Mulia Al-Mawahib merencanakan untuk menjalin kerjasama dengan lembagalembaga lainnya, seperti Fakultas Dakwah UIN Sunan Gunung Djati Bandung dan Badan Pengkajian dan Penerapan Teknologi (BPPT) dalam mengeelola pendidikannya.

Kekhasan lain yang menjadi modal penyelenggaraan pendidikan Madrasah Aliyah (MA) Bina Insan Mulia dimulai dari sistem rekrutmen peserta didik maupun guru yang sangat ketat. Proses prekrutmen peserta didik, atau penerimaan peserta didik baru misalnya, memiliki format khusus yang lebih efektif terutama mempertimbangkan prinsip keadilan dan mutu.

Mulai tahun pelajaran 2013/2014 Madarasah Aliyah (MA) Bina Insan Mulia beroperasi. Pada tahun pertama ini, lokasi penyelenggaraan pendidikan 
Madarasah Aliyah (MA) Bina Insan Mulia bukan di lokasi yang direncanakan. Tetapi menggunakan gedung yang dimiliki Yayasan Mathla'ul Khairiyah yang berlokasi di jalan Tamansari Bawah Kota Bandung. Hal ini di sebabkan, proses pembangunan Madarasah Aliyah (MA) Bina Insan Mulia dalam tahap membangun.

Madarasah Aliyah (MA) Bina Insan Mulia, menerapkan kurikulum Berbasis Kompetensi (KBK). Dan kurikulum Madarasah Aliyah (MA) Bina Insan Mulia. Kurikulum khas tersebut dikemas dalam bentuk struktur program, yang menitik beratkan pada penguasaan basic knowledge of science andtechnology, pendidikan agama, pendidikan dakwah serta penguasaaan bahasa Inggris, bahasa Arab dan bahasa Jepang. Kurikulum tersebut juga diperkaya denga pendidikan yang mengarah pada keterampilan hidup (life sklills), dan menggunakan pendekataan intelektual, kegiatan, keteladanan laboratorium.

Keberhasilan penguasaan matapelajaran yang diberikan oleh para guru. Untuk itu dibawah bimbingan dan koordinasi guru, peserta didik Madrasah Aliyah (MA) Bina Insan Mulia dituntut selalu menghidupkan ruh dan nuansa pesantren, dengan melaksanakan kegiatan keagamaaan bersifat umum, seperti shalat fardhu berjama'ah mengucapkan salam dan berakhlakul karimah.

Kegiatan keagamaan yang sifatnya khusus dilaksanakan untuk meningkatkan pemahaman, penghayatan, dan pengamalan syariat Islam serta nilai-nilai keimanan yaitu kuliah shubuh, tahsin, tahfidz, tafsir Al Qur'an, kajian kitab tematik, pembinaan imam salat fardhu, pembinaan khatib jum'at. Harapannya, berbekal pendidikan keagamaan yang demikian, setiap lulusan Madarasah Aliyah (MA) Bina Insan Mulia dapat berkiprah aktif di masyarakat atau dimana saja dia dibutuhkan.

Adapun Visi Madarasah Aliyah (MA) Bina Insan Mulia adalah berkepribadian unggul yang berkarakter itba'syrariatillah dan itba'sunnatillah, dengan misi mendidik murid menjadi kader-kader pemimpin umat yang beriman, bertaqwa, berkepribadian baik dan berakhlak mulia, menguasai IPTEK, unggul di bidang dakwah dan teknologi komunikasi.

Berdasarkan tujuan pendidikan Islam tersebut, maka tujuan penyelanggaraan pendidikan Madrasah Aliyah Bina Insan Mulia Al- Mawahib merupakan proses improvisasi menurut perkembangan pendidikan Islam saat ini, yang di tentukan bersama sama dengan warga Yayasan Bina Insan Mulia AlMawahib beserta bebrapa ahli dalam bidangnya masing-masing.

Tujuan penyelenggaraan pendidikan Madrasah Aliyah Bina Insan Mulia Al Mawahib adalah usaha untuk:

Pertama, menghasilkan keluaran pendidikn yang memiliki keunggulankeunggulan dalam: (1) kualitas dasar yang meliputi daya pikir, daya kalbu, daya fisik, (2) kualitas instrumental yang meliputi penguasaan ilmu pengetahuan (lunak dan keras) termasuk terapannya yaitu teknologi, kemampuan berkomunikasi, dan 
sebagainya, (3) kemampuan bersaing dan bekerjasama dengan bangsa-bangsa lain.

Kedua, menyiapkan peserta didik agar memilliki kemampuan/kompetensi kunci untuk menghadapi era regionalisasi/globalisasi yaitu: (1) memiliki kemampuan dasar yang kuat dan luas, (2) mampu mengumpulkan, menganalisis, dan menggunakan data dan informasi, (3) mampu mengkomunikasikan ide dan informasi.

Adapun Fungsi Madrasah Aliyah Bina Insan Mulia Al-Mawahib yaitu: 1) pelaksanaan pengembangan dan penyelenggaraan pendidikan; 2) pusat belajar bersama dalam rangka peningkatan dan pengembangan pendidikan masyarakat madani; 3) pusat pengabdian kepada masyarakat dalam rangka mewujudkan masyarakat madani; 4) sebagai agen modernisasi bangsa, Negara, khususnya umat Islam; 5) sebagai lembga pendidikan rujukan dalam pembinaan generasi para da'i; 6) merupakan sumber studi banding bagi pengemabangan pendidikan.

Sasaran Peserta didik yang diterima di Madrasah Aliyah Bina Insan Mulia yaitu harus memiliki kriteria minimal sebagai berikut:

Pertama yaitu Tingkat utama, Kedua yaitu Lulus dan memperoleh tanda kelulusan serta data nilai ujian akhir dari Madrasah Tsanawiyah atau sekolah menengah pertama. Ketiga, Lulus tanpa syarat dalam uji saring yang dilakukan oleh Madrasah Aliyah Bina Insan Mulia Al-Mawahib, yang materi ujinya meliputi bidang akademis (meliputi materi agama, matematika, Bahasa Indonesia, Bahasa Arab dan Bahasa Inggris), bidang non-akademis (meliputi minat dan bakat), bidang sosial (meliputi kondisi tingkat kehidupan sosial dan ekonomi), sehat jasmani dan rohani, tidak terlibat dalam aksi-aksi anarkis dan narkoba.

Motto dari lembaga ini adalah berprestasi unggul, berjiwa pemimpin, berkarya, inovatif, berkarakter itba syari'atillah dan sunnatillah.

Adapun Job description nya adalah sebagai berikut:

Pertama, Pembina pendidikan pesantren bertanggung jawab terhadap seluruh kegiatan pada setiap bagian yang ada di lingkungan pesantren baik internal maupun eksternal. Dengan tugas: (1) menetapkan program pesantren baik jangka panjang maupun jangka pendek; (2) memastikan setiap petugas mendapatkan tugas sesuai dengan keahliannya; (3) memastikan setiap kegiatan pada setiap bagian berjalan sesuai program; (4) mengendalikan kegiatan pada setiap bagian yang ada pesantren; (5) melakukan penilaian terhadap kinerja masing-masing bagan di pesantren.

Kedua, Pembina pendidikan madrasah/Kepala Madrasa bertanggung jawab terhadap seluruh kegiatan pada setiap bagian yang ada dilingkungan Madrasah baik internal dan eksternal. Dengan tugas: (1) menetapkan program pesantren baik jangka panjang maupun jangka pendek; (2) memastikan setiap petugas mendapatkan tugas sesuai dengan keahliannya; (3) memastikan setiap kegiatan 
pada setiap bagian berjalan sesuai program; (4) mengendalikan kegiatan pada setiap bagian yang ada di madrasah; (5) melakukan penilaian terhadap kinerja masing-masing bagan di pesantren.

Ketiga, Waka manajemen pengembangan mutu bertanggungjawab terhadap implementasi dan pemeliharaan sistem manajemen ISO. Keempat, Waka Kurikulum bertanggungjawab terhadap kelancaran kegiatan belajar mengajar pesantren dan madrasah. Kelima, Waka Kemuridan bertanggung terhadap pelaksanaan kegiatan pengembangan diri dan program keahlian / ekstrakulikuler.

Keenam, Waka Humas bertanggungjawab terhadap kegiatan yang terkait dengan kerjasama dunia usaha/dunia industri, masyaraat dan penelusuran tamatan. Ketujuh, Waka sarana bertanggungjawab terhadap ketersediaan sarana prasarana dan bahan ajar yang mendukung keterlaksananya kegiatan belajar mengajar. Kedelapan, Ketenagaan dan Administrasi bertanggungjawab terhadap kegiatan ketatausahaan disekolah.

Kesembilan, Bidang pelayanan dan pengasuhan murid bertanggungjawab terhadap kebutuhan, pengembangan dan kedisiplinan. Kesepuluh, Pengelola keuangan harian bertanggungjawab terhadap pengelolaan keuangan berdasakan pada kebutuhan, pengembangan pendidikan, dan kinerja warga.

\section{Penerapan Fungsi Actuating di Pesantren Bina Insan Mulia Al Mawahib}

Berdasarkan hasil wawancara penulis dengan Kepala Madrasah, (Milla, 31 Juli 2017) diperoleh informasi bahwa rangkaian penerapan fungsi actuating dalam pembinaan tabfidz yang dilaksanakan pesantren Bina Insan Mulia adalah sebagai berikut:

Pertama, perekrutan santri tahfidz Bina Insan Mulia AlMawahib.Berdasarkan hasil wawancara penulis dengan Ibu Milla pada tanggal 31 Juli 2017, menyatakan bahwa santri yang akan masuk ke pesantren Bina Insan Mulia sebelum masuk akan diadakan tes terlebih dahulu. Adapun Tes masuk tahfidz santri diantaranya diawali dengan; (1) melengkapi pemberkasannya misalnya dari prestasi akademik, dan juga prestasi seni, (2) baca tulis Alquran, (3) Tes minat bakat dan (4) kesehatan.

Pendapat serupa juga dikemukakan oleh Asrofil salah satu pembina tahfidz di pesantren Bina Insan Mulia (15 agustus 2017) yang mengatakan bahwa dalam kegiatan tes tahfidz selain tes akademik dan tes prestasi santri, tes tahfidz merupakan hal yang penting karena yang masuk ke pesantren ada yang bacaannya sudah bagus, ada yang sudah punya hafalan yang banyak, dan ada juga yang dari nol. Dengan demikian akan diketahui santri tersebut masuk kelas tahfidz penuh atau kelas tahfidz terbatas. Koordinasi Kegiatan Tahfidz.

Agar setiap kegiatan yang akan dilaksanakan sesuai rencana, maka pembina tahfidz harus memastikan bahwa semua santri telah mengetahui waktu dan tempat kegiatan untuk menyetorkan hafalan. Adapun waktu menyetorkan 
hafalan di bagi menjadi tiga bagian yaitu setelah shubuh, setelah ashar dan setelah isya. Sementara itu tempat pelaksanaan pembinaan tahfidz dilaksanakan di mushola atau di kelas.

Kedua, Mobilisasi dan Alokasi Sumber Daya dalam Pembinaan Tahfidz. Pemantauan dan pengawasan yang dilakukan pembina tahfidz dalam mengarahkan santri dalam menghafal Alquran yaitu dengan memberikan target hafalan sesuai dengan kelas tahfidz masing -masing santri.

Ketiga, Logistik yang di pakai dalam pelaksanaan pembinaan tahfidz yaitu seperti speaker dan mikrofon merupakan alat penyaluran atau penyebaran suara yang berfungsi dalam menghafal Alquran dalam metode tasmi' atau mengaji Alquran bersama di Pesantren Bina Insan Mulia.

Keempat, pemberian motivasi yang diberikan pembina tahfidz terhadap santri dalam menghafal Al-Qur'an adalah dengan diadakannya kegiatan musabaqoh atau tes terbuka, dimana bagi yang hafal tiga juz atau empat juz keatas mendapatkan reward dari pesantren.

Setelah tes selesai, langkah selanjutnya pembina memotivasi para santri dengan cara menumbuhkan rasa percaya diri terhadap santri dalam menghafal Alquran dan mengadakan setoran tiga kali dalam sehari, waktu tahfidz ada tiga waktu 1) setelah shalat shubuh jam 05: $00 \mathrm{~s} / \mathrm{d}$ 06:00 untuk menambah hafalan, setelah ashar jam 16:00 s/d 17:00 untuk muroja'ah atau mengulang hafalan yang sudah hafal dan selanjutnya setelah isya dari jam 19:30 s/d 20:30 menjaga hafalan yang baru. (wawancara dengan Ustadz Asrofil sebagai pembina tahfidz, 15 agustus 2017).

Kelima, Penambahan Hafalan Alquran biasanya dilakukan pada waktu sore atau malam hari, dan untuk santri jika akan naik ke juz selanjutnya maka akan ada tes terlebih dahulu, misalkan juz dua sudah selesai berarti santri tersebut terlebih dahulu di tes di depan temannya dan di simak oleh temannya dan batasan kesalahan membaca paling banyak dalam satu juz itu adalah 20 kalimat. Jika santri tersebut tidak lulus maka santri tidak boleh menambah hafalan juz lagi tapi ketika santri tersebut sudah lulus maka santri tersebut boleh melanjutkan. (wawancara dengan Ustadz Asrofil sebagai pembina tahfidz, 15 agustus 2017).

Keenam, sistematika pembagian kelompok santri tahfidz diantaranya, putra di bagi satu kelompok dengan satu pembina tahfidz, putri dibagi 2 kelompok (satu kelompok terdiri dari kelas X dan XI Sedangkan satu kelompok lagi kelas XII) dengan satu pembina tahfidz karena santrinya lebih banyak. (wawancara dengan Ustadz Asrofil sebagai pembina tahfidz, 15 agustus 2017).

Ketujuh, pemberian sanksi bagi santri yang tidak menghafal sesuai target yang telah ditentukan maka ketika perpulangan atau ketika waktu libur datang maka bagi santri yang belum mencapai target tidak diperbolehkan pulang sebelum target hafalannya diselesaikan. Adapun jika hafalannya tidak kunjung 
beres maka di izinkan pulang akan tetapi ada surat pernyataan bahwa santri tersebut harus menghafal sesuai target yang telah ditentukan selama liburan. Santri yang tidak memenuhui target hafalan juga bisa di turunkan kelasnya, dari tahfidz penuh ke tahfidz terbatas atau ke tahfidz I'dad dan laporannya ada di rapot. Jika santri yang tadinya tahfidz penuh dan memiliki target tiga juz lalu target tiga juz tersebut tidak tercapai maka santri tersebut menjadi kelas I'dad (persiapan). (wawancara dengan Ustadz Asrofil sebagai pembina tahfidz, 15 Agustus 2017).

Kedelapan, penentuan target hafalan jumlah ayat yang di targetkan dalam sehari, target hafalan santri persemester berbeda beda adapun setoran hafalan Alquran bagi santri untuk setiap harinya bebas hanya saja tetap harus mencapai target yang telah di tentukan bagi santri kelas tahfidz tertentu. (wawancara dengan Ustadz Asrofil sebagai pembina tahfidz, 15 Agustus 2017).

Kesembilan, metode pengawasan yang dilakukan oleh pembina terhadap hafalan santri yaitu dengan cara menyimak hafalan santri, santri membacakan hasil hafalannya di depan teman-temannya (wawancara dengan Ustadz Asrofil sebagai pembina tahfidz, 15 Agustus 2017).

Kesepuluh, pengembangan pembinaan tahfidz di pesantren Bina Insan Mulia Al Mawahib, yang sudah memiliki hafalan satu sampai dengan dua juz tinggal pengembangan saja dan santri tersebut di masukkan ke kelas tahfidz penuh dan di kelas tahfidz penuh itu ada target satu semesternya itu tiga juz akan tetapi yang bacaannya masih belum bagus, atau kekuatan hafalannya belum terlalu bagus maka santri tersebut akan di turunkan kelasnya menjadi santri kelas tahfidz terbatas. (wawancara dengan Ustadz Asrofil sebagai pembina tahfidz, 15 Agustus 2017).

Kesebelas, program unggulan pesantren yaitu menjaga agar kualitas dan kuantitas hafalan Alquran seimbang. Karena tidak semua santri yang masuk ke pesantren latar belakangnya sama maka dengan berbagai macam, kemampuannya pun beragam. Kegiatan, dan tugas santri yang padat di sekolah sehingga membuat santri kelelahan dan kurang fokus dalam setoran hafalan Al-Qur'an. Sebagian para santri yang mendaftar ke pesantren Insan Bina Mulia tidak mengetahui bahwasanya di pesantren ini mengharuskan menghafal Al-Qur'an, sehingga calon santri yang mendaftar ada yang mengundurkan diri. (wawancara dengan Ustadz Asrofil sebagai pembina tahfidz, 15 agustus 2017).

Keduabelas, Kegiatan pendukung dan penunjang untuk mencapai target hafalan para santri ketika libur pun diberikan target hafalan, dan ketika kembali kepesantren santri tersebut juga harus menyetorkan hafalannya yang sudah dihafal di rumah dan ini pun menjadi penunjang karena waktu liburanpun tetap di manfaatkan, dan jika ada santri yang tidak beres target hafalannya maka beberapa hari santri tersebut tidak dipulangkan ketika waktu libur datang kalaupun tidak sampai sama sekali ada surat pernyataan bahwa setelah liburan 
misalnya jika santri tersebut tidak memenuhi target maka dalam surat pernyataan tersebutada pernyataan saya santri tersebut siap di hukum. (wawancara dengan Ustadz Asrofil sebagai pembina tahfidz, 15 Agustus 2017).

Penerapan fungsi actuating yang dilakukan di pesantren Bina Insan Mulia Al-Mawahib sesuai dengan teori yang di kemukakan oleh George R. terry dalam buku Sukmadi (2012:77) yang mengemukakan bahwa "actuating is setting all members of the group to want to achieve and to strike to achieve the objective willingly ang keeping with the managerial planning and organizing efforts".

\section{Upaya Pembinaan Tahfidz di Pesantren Bina Insan Mulia Al Mawahib}

Menurut Asrofil, salah seorang Pembina Tahfidz di Pesantren Bina Insan Mulia (15 Agustus 2017), menjelaskan bahwa upaya pembinaan tabfid₹, yang dilakukan dengan beberapa metode, metode tabfidz di pesantren Bina Insan Mulia Al Mawahib diantaranya:

Talaqqi merupakan kegiatan menyetorkan atau memperdengarkan hafalan yang baru dihafal kepada seorang guru atau instruktur. Guru tersebut harus seorang hafizh Alquran yang telah mantap agama dan ma'rifatnya, serta dikenal mampu menjaga dirinya. Proses talaqqi ini dilakukan untuk mengetahui hasil hafalan seorang calon hafizh dan mendapatkan bimbingan seperlunya. Seorang guru tahfizh juga hendaknya yang benar-benar mempunyai silsilah guru sampai kepada Nabi Muhammad saw..

Santri di pesantren Bina Insan Mulia Al Mawahib biasa menyetorkan atau memperdengarkan hafalan untuk di setorkan kepada Pembina tahfidznya pada waktu setelah shubuh dengan diadakannya setoran hafalan Alquran pada setelah shubuh maka hafalan santri akan bertambah. (wawancara dengan Ustadz Asrofil sebagai pembina tahfidz, 15 agustus 2017).

Sima'an yaitu 2 orang punya patner masing-masing kemudian saling mendengarkan dilaksanakan setelah ashar. (wawancara dengan Ustadz Asrofil sebagai pembina tahfidz, 15 agustus 2017).

Tasmi' yaitu memperdengarkan hafalan kepada orang lain baik kepada perseorangan maupun kepada jamaah. Dengan tasmi' ini seorang penghafal AlQur'an akan diketahui kekurangan pada dirinya, karena bisa saja ia lengah dalam mengucapkan huruf atau harakat. Dengan tasmil'seseorang akan lebih berkonsentrasi dalam hafalan. Metode tasmi' juga menjadi salah satu metode tahfidz Alquran di Pesantrn Bina Insan Mulia, biasanya salah seorang santri menbacakan hafalannya di dispeaker yangdan santri yang lainnya mendengarkan atau menyimak dan metode ini di laksanakan sebelum sholat shubuh (wawancara dengan Ustadz Asrofil sebagai pembina tahfidz, 15 agustus 2017).

Metode ngaji bersama yaitu para santri mengaji bersama misalnya ada lima orang atau satu kelas misalnya mengaji juz 30 secara bersama-sama. (wawancara 
N. Sakinah, D. Kuswana, Yuliani

dengan Ustadz Asrofil sebagai pembina tahfidz, 15 agustus 2017).

Kemudian ada juga metode sualan yaitu saling bertanya antar santri tabfidz. dan juga melanjutkan ayat untuk melatih untuk persiapan perlombaan hafalan juga. (wawancara dengan Ustadz Asrofil sebagai pembina tahfidz, 15 agustus 2017).

\section{PENUTUP}

Berdasarkan data yang diperoleh dari hasil analisis, maka dapat ditarik kesimpulan bahwa penerapan fungsi actuating dalam upaya pembinaan tahfidz di pesantren Pesantren Bina Insan Mulia Al Mawahib, yaitu:

Proses pengarahan dalam pembinaan tahfidz di Pesantren Bina Insan Mulia Al Mawahib Perum Gading Tutuka 2, Jalan Raya Banjaran Soreang, Desa Ciluncat Kecamatan Cangkuang Kabupaten Bandung meliputi: diadakannya perekrutan santr, hal ini di maksudkan untuk mendapatkan informasi mengenai bagaimana bacaan para calon santri, bagaimana hafalan para calon santri, dan bagimana prestasi atau keinginan santri dalam menghafal Alquran. Selanjutnya pengarahan dalam pembinaan tahfidz di pesantren Bina Insan Mulia diantaranya yaitu dengan pemberian motivasi, pembagian santri tahfidz, pemberikan sanksi bagi santri yang tidak mencapai target, pengadaan program unggulan tahfidz, penentuan jumlah target hafalan dalam setiap semester, pengawasan dari pembina tahfidz terhadap santri, ,pengembangan pembinaan tahfidz terhadap santri dalam menghafal Alquran, serta penggunaan faktor pendukung atau penunjang santri dalam menghafal Alquran.

Upaya-upaya yang dilakukan di Pesantren Bina Insan Mulia Al Mawahib dalam pembinaan tahfidz terhadap santri agar senantiasa menjaga kualitas dan kuantitas hafalan adalah dengan menggunakan metode -metode sebagai berikut:

Pertama, Talaqqi merupakan kegiatan menyetorkan atau memperdengarkan hafalan yang baru dihafal kepada seorang guru atau instruktur. Guru tersebut harus seorang hafizh Alquran yang telah mantap agama dan ma'rifatnya, serta dikenal mampu menjaga dirinya. Proses talaqqi ini dilakukan untuk mengetahui hasil hafalan seorang calon hafizh dan mendapatkan bimbingan seperlunya. Seorang guru tahfizh juga hendaknya yang benar-benar mempunyai silsilah guru sampai kepada Nabi Muhammad saw. Santri di pesantren Bina Insan Mulia Al Mawahib biasa menyetorkan atau memperdengarkan hafalan untuk di setorkan kepada Pembina tahfidznya pada waktu setelah shubuh dengan diadakannya setoran hafalan Alquran pada setelah shubuh maka hafalan santri akan bertambah.

Kedua, Sima'an yaitu 2 orang punya patner masing-masing kemudian saling mendengarkan dilaksanakan setelah ashar.

Ketiga, Tasmi' yaitu memperdengarkan hafalan kepada orang lain baik kepada perseorangan maupun kepada jamaah. Dengan tasmi' ini seorang 
penghafal Al-Qur'an akan diketahui kekurangan pada dirinya, karena bisa saja ia lengah dalam mengucapkan huruf atau harakat. Dengan tasmil'seseorang akan lebih berkonsentrasi dalam hafalan. Metode tasmi' juga menjadi salah satu metode tahfidz Alquran di Pesantrn Bina Insan Mulia, biasanya salah seorang santri menbacakan hafalannya di depan temannya, sementara santri yang lainnya mendengarkan atau menyimak, dan metode ini di laksanakan sebelum sholat shubuh. Metode ngaji bersama yaitu para santri mengaji bersama misalnya ada lima orang atau satu kelas misalnya mengaji juz 30 secara bersama-sama.

Kemudian ada juga metode sualan yaitu saling bertanya antar santri tahfidz dan juga melanjutkan ayat untuk melatih untuk persiapan perlombaan hafalan juga.

Dari penelitian ini, penulis memberikan rekomendasi karena proses pengarahan dalam pembinaan tahfidz di Pesantren Bina Insan Mulia Al Mawahib Perum Gading Tutuka 2, Jalan Raya Banjaran Soreang, Desa Ciluncat Kecamatan Cangkuang Kabupaten Bandung sudah baik dan sudah sesuai dengan teori, maka penulis menyarankan agar Pesantren Bina Insan Mulia Al Mawahib senantiasa mempertahankan dan bahkan bisa meningkatkan setiap kegiatan pembinaan tahfidz yang dilaksanakan sehingga menghasilkan santri yang baik.

Penelitian yang penulis teliti ini berfokus pada penerapan fungsi actuating pesantren dalam upaya pembinaan tahfidz agar bisa ditindak lanjuti peneliti lain mengenai manajemen pesantren yang lebih komperhensip karena penulis merasa belum sempurna dan masih banyak kekurangan dalam proses penelitian ini.

\section{DAFTAR PUSTAKA}

Absor, S.M.U. (2005). Peranan Manajemen Yayasan Raudhoh Al Aitam dalam Meningkatkan Kreatifitas Anak Yatim. Skripsi, Jurusan Manajemen Dakwah, UIN Sunan Gunung Djati, Bandung.

Ali, M. (1973). Kamus Lengkap Bahasa Indonesia Modern. Jakarta: Pustaka

Albani, M. N. (1985). Masa Depan Pesantren. Jakarta: Gema Insani

Baso, A. (2013). Pesantren Studies. Jakarta: Pustaka Afid

Dhofier, Z.( 1982). Tradisi Pesantren hidup Kyai, Jakarta: LP3ES

Galba, S. ( 2004). Pesantren Sebagai Wadah Komunikasi. Jakarta: Ird Pres.

Halim, A. (2005). Manajemen Pesantren, Yogyakarta: Pustaka Pesantren

Hasibuan, M.S.P.( 2010). Organisasi dan Motivasi. Jakarta: Bumi Aksara , Hasibuan, M.S.P.( 2006). Manajemen. Jakarta: Bumi Aksara

Kurniawan, A. ( 2016). Manajemen Strategik Pondok Pesantren Dalam Menyiapakan Kader Da’i Yang Berkualitas (Studi deskriptif di Pondok Pesantren Terpadu Darussyifa Al Fitroh Perguruan Yaspida Sukabumi Jawa Barat). Skripsi, Jurusan Manajemen Dakwah, UIN Sunan Gunung Djati 


\section{Bandung.}

Lubis, M.R. (1992). Pemikiran Soekarno Tentang Islam. Jakarta: C.V. Mas Agung

Mundzier, (2005). Manajemen Pondok Pesantren. Jakarta: Diva Pusta

Munir, M. (2006). Manajemen Dakwah, Jakarta.: Kencana Prenada Media Group

Nurafifah, S. ( 2013). Teknik Komunikai dalam Pembinaan Alquran Terbadap Anak Asub Yatim Piatu dan Fakir Miskin Amanab Pondok Labu Jakarta Selatan. Diakses 13 januari 2017 dari http://repository.uinjkt.ac.id/ dspace/bitstream/123456789/31711/1/SITI\%0NURAFIFAH-FDK.pdf,

Nurhayati, I. (2003). Aplikasi Fungsi Manajemen Dalam Penyeklenggaraan Bimbingan Ibadah Haji Pada Yayasan Haji Daarul Ihsan (Yahdi) PT. Telkom. Skripsi, Jurusan Manajemen Dakwah, UIN Sunan Gunung Djati Bandung

Nurrika, S. ( 2003) Motivasi Santri dalam Mengikuti Bimbingan Keagamaan di Pondok Pesantran Syamsul Ma'arif (Studi deskriptif di Cileunyi Kulon Bandung). Skripsi, Jurusan Manajemen Dakwah, UIN Sunan Gunung Djati Bandung.

Sari, S. N. (2003). Kebijakan dan Strategi Pimpinan Pondok Pesantren dalam Upaya Pengembangan Pondok Pesantren. Skripsi, Jurusan Manajemen Dakwah, UIN Sunan Gunung Djati Bandung.

Sa'dulloh, (2008). 9 Cara Praktis Menghafal Alquran, Jakarta: Gema Insani

Setiawan, A.I. (2015). Budaya Organisasi Dalam Lembaga Islam Ilmu Dakwah: Academic journal for Homiletic Studies, 90-110.

Steenbrink, K. A. (2018). Pesantren Madrasah Sekolah, Jakarta: LP3ES

Sumarni, E. (2016). Implementasi Manajemen Pembinaan Manasik pada Calon Jama'ah Haji (Studi deskriftif pada KBIH Al Mu'awanah CibiruBandung). Skripsi, Jurusan Manajemen Dakwah, UIN Sunan Gunung Djati Bandung.

Vitria, R. ( 2003). Proses Perencanaan Program Daarul 'Aitam Dhu'afa Pondok Pesantren Modern Assalam Dalam Upaya Pemberdayaan Ekonomi Umat. Skripsi, Jurusan Manajemen Dakwah, UIN Sunan Gunung Djati Bandung.

Ziemek, M. (1986). Pesantren dalam Perubahan Sosial. Jakarata: P3M 